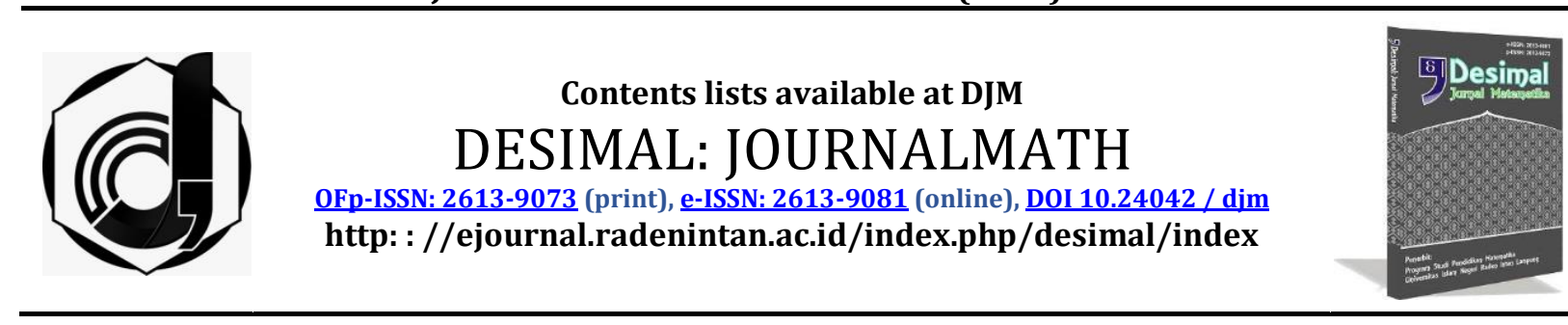

\title{
The Profile of Students' Learning Difficulties in Concepts Mastery in Calculus Course
}

\author{
Melkior Wewe \\ STKIP Citra Bakti, Indonesia
}

\section{ARTICLE INFO}

$\begin{array}{ll}\text { Article History } \\ \text { Received } & : 30-03-2020 \\ \text { Revised } & : 07-04-2020 \\ \text { Accepted } & : 09-05-2020 \\ \text { Published } & : 20-05-2020\end{array}$

Keywords:

Learning Difficulties; Concepts mastery; Calculus.

* Correspondence: E-mail: melkiorwewe1@gmail.com

Doi:

$\underline{10.24042 / d j m . v 3 i 2.6421}$

\begin{abstract}
This research was conducted because of the low students' learning outcomes in concepts mastery in calculus course. The purpose of this research was to obtain the concepts mastery profile of the second semester students of the Mathematics Education Study Program. The results obtained in this study were used as reference materials for calculus course and to influence the lecturers to find the right approach or learning model in order to improve students' concept mastery. This study employed the descriptive-quantitative method. The results showed that the students' were having learning difficulties in concepts mastery in calculus course. The learning difficulties were caused by low concepts mastery and low mathematical principles understanding that led the students into wrong process skills. The difficulties experienced by the students such as difficulties in understanding the concepts and principles of the absolute value of the material, limit functions, and derivatives so that their answers were not as expected.
\end{abstract}

http://ejournal.radenintan.ac.id/index.php/desimal/index

\section{INTRODUCTION}

The $21^{\text {st }- \text { century }}$ will fundamentally change the human life due to competitions in the science and technology. Indonesia, as a developing country, needs to prepare professional, credible, and competitive resources Wewe and You (2019).

Khan in Tillaar cited by Wewe and Kau (2019) states that if a new challenge meets and outdated mindset, failure will surely come. New challenges demand new thought processes to produce quality and competitive outcomes. A good education outcomes needs to be supported by a good environment so that students can develop all the potential possessed optimally since it can be useful for the self-development and society in general. Globally competent resources are resources that are capable of involving critical, creative, systematic, and logical abilities, as well as able to work with others. As stated by the Ministry of National Education (2006), this ability must be developed in the process of learning mathematics because it has an interrelated structure between one concept with another in everyday life so that everyone who studies mathematics has a rational thinking skill. 
Decimal, 3 (2), 2020 - 162

Melkior Wewe

Mathematics must be taught to all students at every level of education.

Mathematical literacy becomes the important aspect of educational goals at today's society. One is said to have mathematical literacy when someone has the specific mathematical competencies, Ljerka Jukić Matić (2014). Ljerka's statement explains that mathematics literacy is a program in the world of education to achieve the goals of mathematics education which is very important today.

Niss states that, as quoted by Matić (2014), there are eight known competencies in mathematics, namely mathematical thinking, posing and solving mathematical problems, modeling, reasoning, representing, handling mathematical symbols and formulas, communicating, and utilizing aids and tools. The eighth mathematical competencies should be developed at all levels of educations. Niss's statement explains that there are eight competencies that must be possessed by students in the elementary, secondary and tertiary levels of education such as (1) mathematical reasoning and thinking,

argumentation, communication, mathematical modeling (5) posing and solving problem, (6) representation, (7) symbols, and (8) media and technology.

Kemendikbud (2013) states that that the context of learning in the $21^{\text {st }}$ century applies creativity, critical thinking, communication skills, collaboration, community and skills, as well as character. The learning process in the era of industry revolution 4.0 requires the use of online-based learning models that contain usefuls contents for educational development. This situation is highly irrelevant to the current application of education which is still dominated by the teacher that does not provide an opportunity for students to explore the surrounding environment Wewe (2019). Thus, mathematics learning in the classroom needs to be reformed Tandaliling, (2011).

Calculus is a branch of mathematics that requires a number of basic materials as a prerequisite in mastering its basic concepts by using patterns, reasoning, communicating an idea, compiling evidence to solve a mathematical problem. Simmons states that, as cited by Sembiring (2017), trigonometry, algebra, and geometry are basic knowledge as prerequisites for studying calculus course. It is supported by Leithold, as quoted by Wahyuni (2017), to learn calculus, knowledge of certain mathematical concepts namely trigonometry, algebra and general high school geometry must be possessed.

Calculus is a topic in mathematics learning and is a core course in mathematics education study programs. The concept of Calculus was first developed in Egypt, Greece, China, India, Iraq, Persia and Japan while the development of the basic principles of calculus was started in Europe by Isaac Newton and Leibniz in the $17^{\text {th }}$-century. Calculus has two branches, namely differential calculus and Integral calculus. Calculus applications are very broad in the fields of science, economics, and engineering and can solve various problems that cannot be solved using elementary algebra, Donald R. LaTorre, et. (2007).

The second semester students of Mathematics Education Study Program at STKIP Citra Bakti consisted of 11 students. Five of them had came Mathematics and Natural Sciences major background while six of them had Social Sciences major background. The learning objectives at the tertiary level education depend on the subject. Calculus is a very common topic at the senior high school level and is a core course in Mathematics Education Study Program. Calculus is 
needed in various disciplines in increasing the predictive power of the science and is something imperative because it is a means to further deductive reasoning which is well known for its very hierarchical nature and efficient language produces. In conducting quantitative analysis to a problem, mathematical modeling is the basic requirement by applying the understanding of various concepts and principles, Mutakin (2015). Seeing the benefits of calculus, students are required to master their abilities well. Calculus lessons are an entry point in learning higher mathematics.

Tias and Wusqa (2015) define learning difficulties as a condition experienced by someone because of their failure to achieve learning goals in the learning process due to the obstacles during the learning process. Furthermore, Januarti, as cited by Wantika and Nasution (2019), states that students who get low grades are said to be students who have learning difficulties. Understanding each student's character can be done with an individual and instructional approach.

Learning difficulties experienced are commonly in understanding the basic concepts, principles, and skills of calculus. Concepts mastery is the ability to understand a mathematical problem and solve mathematical problems using mathematical concepts that are interrelated precisely in everyday life. Wahyuni (2017) explains that the inhibiting factors of learning difficulties in the learning process are limited concepts, wrong delivery of concepts, and very minimal implementation of concepts. Based on the mentioned definition, it can be concluded that learning difficulties are a condition where a student fails in achieving the learning objectives caused both internal and external factors. The internal factors cover the learning motivation, concepts mastery, principles, and skills in solving mathematical problems.

The students of the Mathematics Education Study Program at STKIP Citra Bakti were having difficulties in solving calculus concepts. Based on the midterm test of the 2019/2020 academic year, $75 \%$ out of 11 students failed the calculus course. They did not master the concepts properly. Based on the researchers' experience, if students cannot master the concepts, principles, and skills properly, they will experience learning difficulties in advance courses such as advanced calculus or other subjects.

Research on students' learning difficulties profile in concepts mastery in calculus course needed to be conducted. The purpose of this research was to find out the profile of students' learning difficulties in understanding calculus concepts. The results of ths research are expected to find solutions by applying the best strategies, approaches, or models to improve students' understanding of the basic concepts of calculus because calculus courses are core subjects and become the requirement for other subjects.

\section{METHOD}

This is a descriptive research with qualitative and quantitative approaches. The quantitative approach was used to measure the concepts mastery through written tests in the form of description questions and interview method to obtain answers from each student regarding the learning difficulties in calculus concepts mastery. This research was conducted in the academic year $2019 / 2020$. The subject of the research were 11 second semester students of Mathematics Education Study Program at STKIP Citra Bakti. The subjects had completed the calculus I course. The qualitative analysis was done using the 
Decimal, 3 (2), 2020 - 164

Melkior Wewe

Miles and Huberman model as presented

in Figure 1.

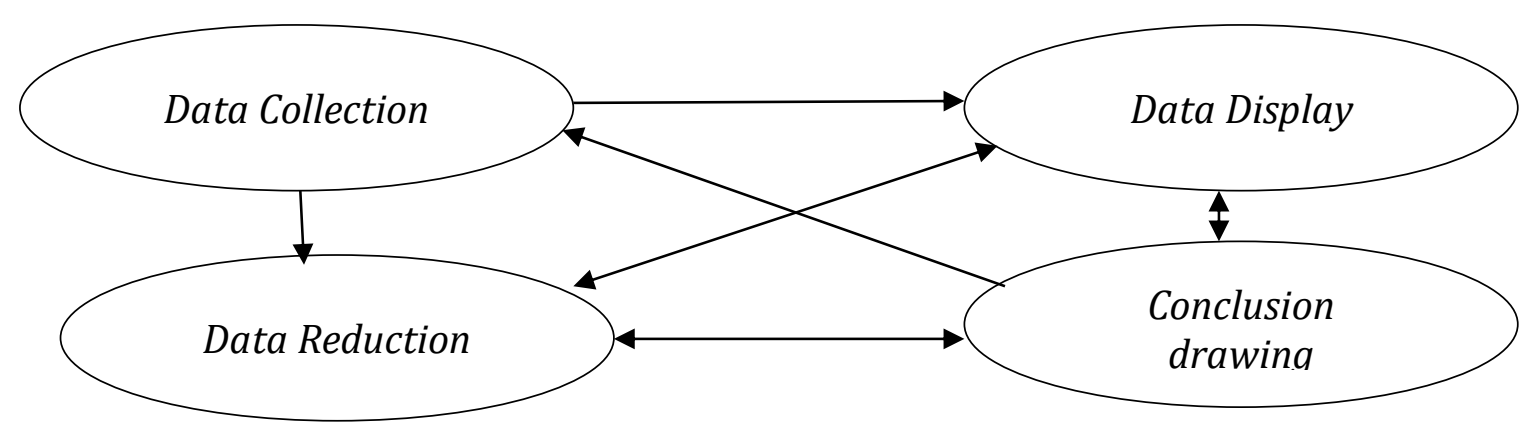

Figure 1. Chart of Qualitative Data Analysis Techniques for the Miles \& Huberman Model

Figure 1 is the description of the stages of the qualitative data analysis. The stages are started by collecting the data, both the interviews and tests. Then, the data display and data reduction stages are carried out to select and focus on the research object, simplify the findings during the study, and transform the rough data found during the research activities, namely the results of tests and interviews. Next is the presentation of data that can be used as a basis for drawing conclusions.

\section{RESULTS AND DISCUSSION}

The data presented in table 1 containing grades as a result of midterm test on one variable linear inequality, Function graph, Function Limit, and Derivative topics.

Table 1. Students' Concepts Mastery Levels

\begin{tabular}{|c|c|c|c|c|}
\hline \multirow[t]{2}{*}{ No. } & \multirow[t]{2}{*}{ Material } & \multirow[t]{2}{*}{ Indicator } & \multicolumn{2}{|c|}{ Concepts Mastery Level } \\
\hline & & & $\begin{array}{l}\text { Having Concept } \\
\text { Mastery Difficulty }\end{array}$ & $\begin{array}{l}\text { Not Having } \\
\text { Concept Mastery } \\
\text { Difficulty }\end{array}$ \\
\hline 1 & $\begin{array}{l}\text { One Variable } \\
\text { Linear Inequality }\end{array}$ & $\begin{array}{l}\text { Determining the set } \\
\text { of solutions using } \\
\text { algebra and lines. }\end{array}$ & 4 students $=57.14 \%$ & $\begin{array}{l}7 \text { students }=42 \text {, } \\
86 \%\end{array}$ \\
\hline 2 & $\begin{array}{l}\text { Absolute Value } \\
\text { Inequalities }\end{array}$ & & 8 students $=72,73 \%$ & $\begin{array}{l}3 \quad \text { students } \\
27.27 \%\end{array}$ \\
\hline 3 & Limit & $\begin{array}{l}\text { Determining } \\
\text { Algebraic Function } \\
\text { Limit. }\end{array}$ & 3 students $=54.55 \%$ & $\begin{array}{l}5 \quad \text { students } \\
45.45 \%\end{array}$ \\
\hline 4 & Limit & $\begin{array}{l}\text { Determining } \\
\text { trigonometry } \\
\text { function Limit. }\end{array}$ & 9 students $=81,82 \%$ & $\begin{array}{l}2 \quad \text { students } \\
18.18 \%\end{array}$ \\
\hline 5 & Derivative & $\begin{array}{l}\text { Determining the } \\
\text { derivative and value } \\
\text { of a derivative } \\
\text { function. }\end{array}$ & 9 students $=81.82 \%$ & $\begin{array}{l}2 \text { students = } \\
18.18 \%\end{array}$ \\
\hline 6 & Derivative & $\begin{array}{l}\text { Determining the } \\
\text { value of aderivative } \\
\text { function. }\end{array}$ & 9 people $=81.82 \%$ & $\begin{array}{l}2 \text { people = } \\
18.18 \%\end{array}$ \\
\hline
\end{tabular}

Table 1 contains the data of students' mid-term test. Based on the data, the absolute inequality value obtained a percentage of $72.73 \%$, 
Decimal, 3 (2), 2020 - 165

Melkior Wewe

algebraic limit functions obtained a percentage of $81.82 \%$, and the derivatives and determines the value of the derivative function obtained a percentage of $81.82 \%$.

The data showed that the students who took the calculus course were having difficulty to understand the basic concepts of calculus. The 6 test questions could not be completed within the given time. Students were accustomed to using media. They displayed the old pattern of high school by just for the exam preparation. However, the students had good selfdevelopment ability and had high motivation to learn. The following are the students' works as data used to determine the level of concept mastery difficulty.

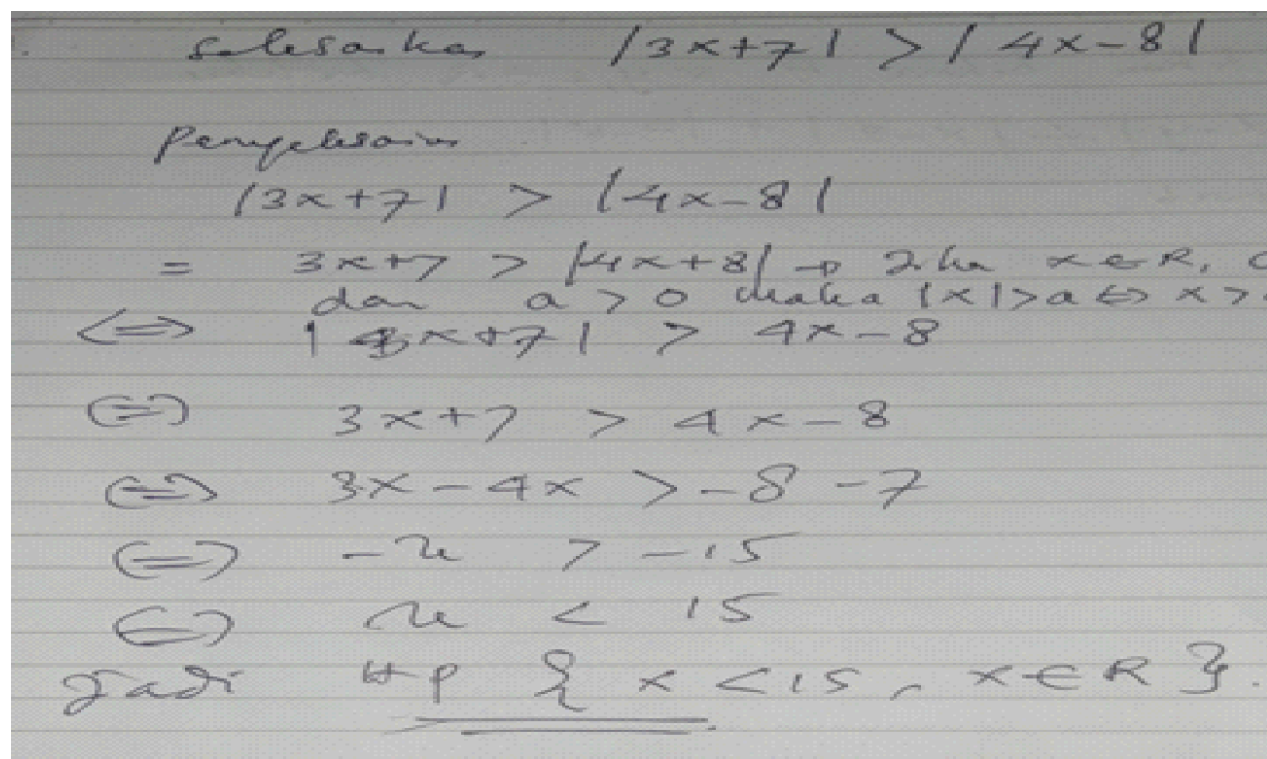

Figure 2. Student's Answer in Determining the Absolute Inequality Value

The problem above should be completed by using the absolute value theorem that is if $\mathrm{x}$ and a are real numbers and a is more than 0 , then a is more than 0 , so $\mathrm{x}$ is less than negative a or $\mathrm{x}$ is more than a. The picture above is the result of student's work showing that he did not yet understand the concepts and principles of absolute value. Students' understanding of definitions and principle is related to their understanding of theorems. The skills aspect is related to students' ability to use concepts and principles in completing mathematical problems and to obtain an appropriate solution based on the problem. Based on the results of student's work above, it can be concluded that the students experienced learning difficulties. They could not master the concepts, principles, and skills well. The results of the interviews showed that they forgot the concepts and principles of absolute value. This problem was caused by the conventional learning patterns in the high school level where the teacher did not connect the interrelated theorems and concepts. 
Decimal, 3 (2), 2020 - 166

Melkior Wewe

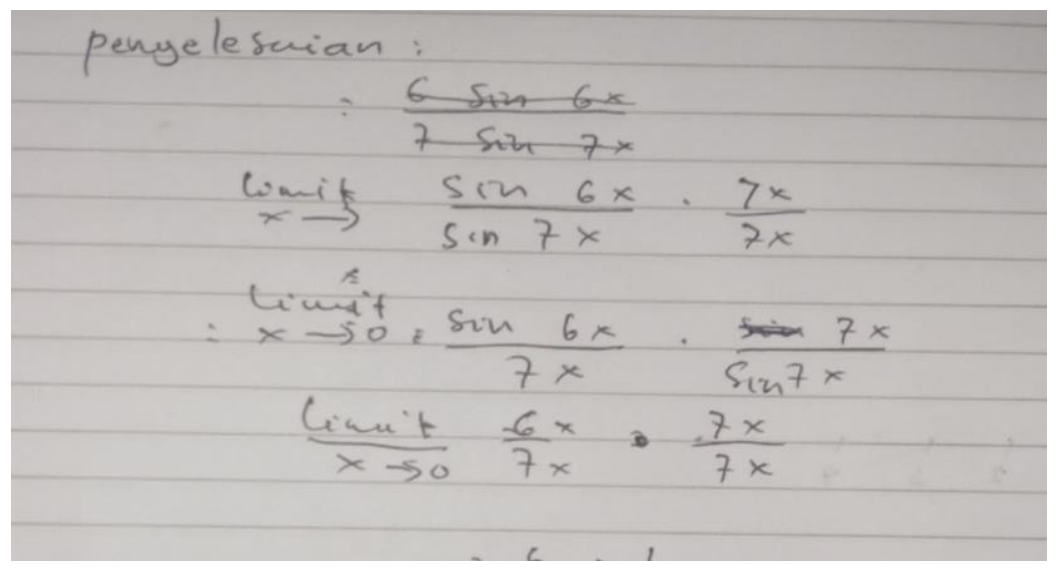

Figure 3. Student's Answer in Determining Trigonometric Function Limits

Figure 3 is the result of student's work in determining the trigonometric function limits. It shows that the student experienced learning difficulty. The results of personal interviews with the student reveal that the students forgot the trigonometric limit concept so that it affected his ability to calculate the operations

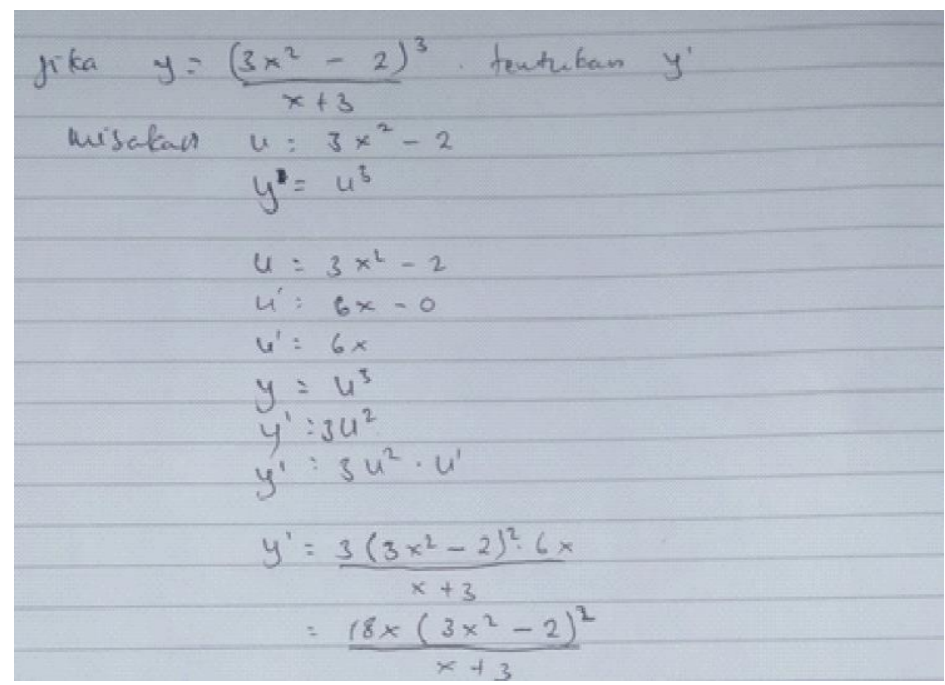

Figure 4. Student's Answer to Derivative Function Problem

The errors committed by the and derivative rank. It was caused by student based on Figure 4 are errors in inappropriate use of time allotment so derivative concepts, derivative division, that the final solution was incorrect.

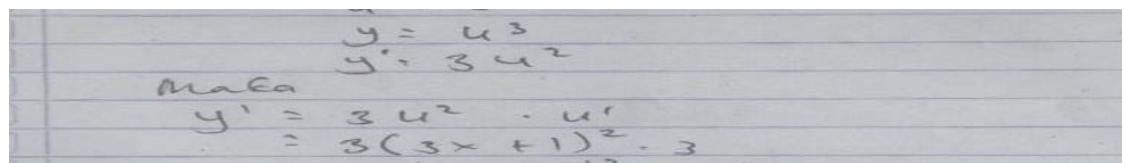

Figure 5. Student's answer in Determining the Value of a Derivative Function

Figure 5 displays the student's answer in determining the derivative value of a given derivative function. The results of the student's work did not match the answer. The results of interviews discovered that the student did not understand the problems given and incorrect application of quotient rules and rank derivative concepts. 


\section{Decimal, 3 (2), 2020 - 167 \\ Melkior Wewe}

The data analysis revealed that the students were having difficulty in understanding the concepts to solve the problems given and understanding of the principles related to the theorem or the nature of absolute value theorem, the limit theory, and the properties of the algebraic derivatives function. The learning difficulties experienced by the students of the Mathematics Education Study Program at STKIP Citra Bakti caused their midterm test scores did not achieve the minimum passing grade. The students did not understand the concepts and mathematical principles well so that it affected their mathematical skills. It is in line with Wahyuni (2017) that the inhibiting factors of learning difficulties in the learning process are limited concepts, incorrect delivery of concepts, and minimum implementation of concepts. The concepts mastery is very important to be mastered by students, especially in calculus course. In line with the opinion of Pitaloka (2013), the concept mastery makes it easier for students not only to master the formula, but also to understand the meaning contained in mathematics learning so that the learning objectives can be achieved.

Concepts mastery is the ability to understand and solve mathematical problems using mathematical concepts. In studying calculus, the concepts mastery must be mastered by students because calculus is a prerequisite material for other courses and the use of calculus concepts is very broad in the fields of science, economics, and engineering. It can solve various problems that cannot be solved using elementary algebra. For students, not only memorizing the material or doing practice questions that are important, but also the process of concepts mastery as a provision in learning other material and solving problems in daily life.

Calculus course is a very common topic at secondary level education and is the core course in mathematics education study programs. Completing problem solving in calculus course is very difficult. Students often make mistakes in solving mathematical problems. In solving calculus problems, students must understand the concepts, principles, and skills. The statement above is in line with the opinion of NP Loc, quoted by Nguyen \& Tran Thai Ho (2014), that calculus has highly intrinsic complexity and often involves infinite process; therefore, students will encounter difficulties and obstacles while studying the subject and will commit many errors when solving calculus problems.

The results of the research reveal that the students were having difficulty. The learning difficulties are caused by internal factors and external factors. The internal factors such as concepts mastery and low mathematical principles understanding affect the process skills. They had difficulty in understanding the concepts and principles of absolute value, limit functions, and derivatives so that the questions could not be answered properly. The external factors obtained from interviews such as inaccuracy in managing time so that the questions given cannot be solved within the time allocation. One object in mathematics is concept mastery. The concept mastery in learning calculus is very important because it can help in solving mathematical problems naturally and without any difficulties.

Some of the mathematical objects are interrelated concepts, principles, procedures and skills because concepts mastery is a basic skill possessed by students in understanding mathematical problems and to solve mathematical problems properly.

The results of this study are in line with the research of Wantika and Nasution (2019), Tias and Wutska (2015), that learning difficulties experienced by students in mathematical concepts mastery are internal and external factors, 


\section{Decimal, 3 (2), 2020 - 168 \\ Melkior Wewe}

such as learning motivation, concepts understanding, principles, low mathematical skills, and improper time management.

\section{CONCLUSIONS AND SUGGESTIONS}

Based on the results of data analysis and discussion, it can be concluded that the students experienced learning difficulties. Learning difficulties are caused by low concepts mastery and low understanding of mathematical principles which impact the process skills. The difficulties experienced are difficulties in understanding the concepts and principles of absolute value, limit functions, and derivatives. Empirically, the error found is the inaccuracy in managing time so that the problems given cannot be solved within the time allocation.

The results of this study serve as consideration in managing the learning process using approaches, strategies, models and learning methods to hone the concepts mastery, principles, or theories in calculus so that the students can solve problems in calculus. They also serve as a consideration for further researchers in managing the learning process.

\section{REFERENCES}

A.A. Wedaring Tias dan Dhoriva Urwatul Wutsqa (2015). Analisis Kesulitan Siswa Sma Dalam Pemecahan Masalah Matematika Kelas XII IPA Di Kota Yogyakarta. Jurnal Riset Pendidikan Matematika. 28-29.

Br. Sembiring Ribka Kariani (2017). Analisis Kesalahan Mahasiswa Dalam Mata Kuliah Analisis Komplek. Prosiding. Seminar Nasional Pendidikan Dasar Universitas Negeri Medan. 213-219

Depdiknas. (2006). Permendiknas No 22 Tahun 2006 Tentang Standar Isi. Jakarta : Depdiknas

Kemendikbud. (2013). Kerangka Dasar dan Struktur Kurikulum 2013. Jakarta: Kemendikbud.

Latorre, Donald R.; Kenelly, John W.; Reed,
Iris B.; Biggers, Sherry (2007), Calculus Concepts: An Applied Approach to the Mathematics of Change, Cengage Learning, hlm. 2.

Ljerka Jukic Matic. (2014). NonMathematics Students' Reasoning In Non-Routine Calculus Tasks. EPESS. He Eurasia Proceedings of Educational \& Social Sciences. 124-134.

Mutakin, Tatan Zaenal. (2013). Analisis Kesulitan Belajar Kalkulus 1 Mahasiswa Teknik Informatika. Formatif. Jurnal Ilmiah Pendidikan MIPA. 49 - 60.

Nguyen Phu Loc dan Tran Cong Thai Ho. (2014). A Survey of 12th Grade Students 'Errors In Solving Calculus Problem. Journal Online. International Journal Of Scientific \& Technology Research. 107-108.

Pitaloka, Y.D. (2013). Keefektifan Model Pembelajaran Matematika Realistik Indonesia terhadap Kemampuan Pemahaman Konsep Matematika. Unnes Journal of Mathematics Education. 1-8.

Tandaliling. 2011. Peningkatan Pemahaman dan Komunikasi Matematis serta Kemandirian Belajar Siswa SMA Melalui Strategi PQ4R dan Bacaan Refutation Text. Bandung: Respositoty.upi.edu

Wahyuni, A. (2017). Analisis Hambatan Belajar Mahasiswa Pada Mata Kuliah Kalkulus Dasar. Jurnal JNPM Uurnal Nasional Pendidikan Matematika),1021

Wantika dan Sri Purwanti Nasution (2019) Analisis Kesulitan Belajar dalam Memahami Kecemasan Peserta Didik pada Pembelajaran Matematika. Desimal. Jurnal Matematika, 49-57.

Wewe, Melkior dan Kau Hildegardis. (2019). Etnomatika Bajawa: Kajian Simbol Budaya Bajawa Dalam Pembelajaran Matematika. JIPBC. Jurnal Ilmiah Pendidikan Citra Bakti,121-133. 